\title{
Accountability Reporting Objectives of Māori Organizations
}

\author{
Russell Craig* \\ Portsmouth Business School \\ Faculty of Business and Law \\ University of Portsmouth \\ Richmond Building \\ Portland Street \\ Portsmouth \\ Hampshire, UK \\ Email: Russell.Craig@portsmouth.ac.uk \\ $+61(0) 478409619$ \\ Rawiri Taonui \\ Massey University \\ Palmerston North \\ New Zealand \\ Email: R.Taonui@massey.ac.nz
}

\author{
Susan Wild \\ Department of Accounting and Information Systems \\ University of Canterbury \\ Christchurch \\ New Zealand \\ Email: Susan.Wild@canterbury.ac.nz
}

\section{Lúcia Lima Rodrigues}

School of Economics and Management

University of Minho

Braga

Portugal

Email: LRodrigues@eeg.uminho.pt

* Corresponding Author 


\section{ABSTRACT}

Purpose - This viewpoint highlights the accountability reporting objectives of four Māori-controlled organizations. The examples cited reflect the core values of the indigenous Māori people of New Zealand (Aotearoa) and help demonstrate how these values are manifest in the accountability reporting of Māori-controlled organizations.

Design/methodology/approach — Narrative sections of a total of ten annual reports of two small and two large Māori organizations, drawn variously from their financial years ending in the calendar years 2009 to 2014, are read closely. These organizations represent diverse tribal and regional associations in terms of size, scope, structure; and in terms of the business, social and cultural activities they pursue.

Findings - Three core Māori values are identified: spirituality (wairuatanga); intergenerationalism and restoration (whakapapa); and governance, leadership and respect (mana and rangatiratanga). The commitment to these values, and the way this commitment is reflected in accountability reports of Māori organizations, are presented.

Originality - The examples provided, and the associated discussion, should help inform reporting initiatives of organizations that are seeking better accountability in terms of their long-term engagement with indigenous communities, the environment, and broader society.

Keywords: Accountability, Indigenous, Māori, Culture, New Zealand, Reporting

Paper type: Viewpoint

\section{Introduction}

This viewpoint introduces empirical examples to illustrate the accountability reporting objectives of four Māori-controlled organizations in New Zealand (Aotearoa). As with Craig et al. (2013; 2018), Wild (2013), Spiller et al. (2011), McNicholas (2009), Jacobs (2000), and others, we believe there is considerable potential for accountability reporting in non-indigenous communities to be informed by indigenous perspectives. We regard "accountability reporting" to be an open and transparent accounting (and not necessarily a financial accounting report) of the actions for which an entity should be held responsible.

We provide examples of accountability reporting objectives and practices for each of three core values that are intrinsic in Māori culture. These are identified by Craig et al. (2018) as:

wairuatanga and tikanga - spirituality and customary belief;

whakapapa - inter-generationalism and restoration; and

mana and rangatiratanga - governance, leadership and respect.

These three core Māori values interconnect humankind, spirituality and stewardship (Henry and Pene, 2001). The examples we introduce are taken from the narrative sections of annual reports of Māori-controlled organizations. They illustrate how these three core values are committed to, and accommodated in, the accountability reports of the Māori organizations to address issues of sustainability, intergenerational equity, and governance. Our purpose in presenting them is to encourage development of a form of business reporting that better serves 
future interests, and the interests of communities and the environment. In this sense, we appear to be of like mind with McNicholas (2009) and Wild (2013).

McNicholas (2009, p. 320) has drawn attention to the benefits of reflecting indigenous worldviews in Western financial reporting and accounting frameworks. She argues that such reflection would help accountants develop a better "... understanding of, and sensitivity towards ... social, environmental and cultural imperatives..." A further benefit of an indigenous worldview is that it encourages organizations not to physically and morally distance themselves from the multi-cultural societies in which they exist.

However, we should be mindful of the challenge to foster participatory processes and contestations that will help us to think about accounting in new ways (Brown and Dillard, 2013). Wild (2013, p.18) suggests that accounting metrics which are cognisant of "contextsensitive cultural values" could contribute a more "appropriate and useful means of measuring and reporting accountability towards stakeholders." She cites with approbation an alternative set of valuation metrics that was recommended for application to the governance and management of a Mãori education institution by Winiata (2006). She advocates their use for all "public benefit entities" holding heritage, cultural and community assets.

Generally, the Māori world-view values co-operation over competition, and preserves natural resources for future generations. Māori regard "value" as something that is both intrinsic and extrinsic, and resides in phenomena which are financial and non-financial, tangible and intangible, and seen and unseen (Craig et al., 2013; Wild, 2013; Winiata, 2006; Durie, 2006; Durie et al., 2002; Jacobs, 2000). Love (2017) provides a useful review of some literature that elaborates on the meaning of Mãori values and the importance of understanding the Mãori values that underlie the conduct of businesses by Mãori in New Zealand.

Mãori values are evident in the operation of, and reporting by, Māori-controlled organizations (including government authorities, broadcasters, and commercial ventures of $i w i$ (tribes)). These organizations adhere to a general core of beliefs that value spirituality, collective ownership, connectedness to the land, and preservation of the natural and physical environment in honour of past generations and for future generations. In contrast, conventional accounting thought and practice is dominated by the ideologies of Western capitalism, based on an "... ambient view of human endeavour that is characterized by tangibility, individualism, short-termism, competition, material achievement, independence, and profit" (Craig et al., 2013), p. 6).

The empirical examples we cite are drawn from narrative sections of a total of ten annual reports, for financial years ending during calendar years 2009 to 2014. Note that we do not 
explore whether the performance claims made in any statements we cite from these sources have been achieved or whether they might more accurately be characterized as "rhetorical flourishes."

The four Māori organizations represented are:

- Te Rūnanga o Ngāi Tahu [NT].

- Waikato-Tainui Te Kauhanganui Incorporated [WTTKI].

- Te Whānau o Waipareira Trust [TWOWT].

- Māori Television [MT].

These four Māori organizations represent diverse tribal and regional associations in terms of size, scope, structure, and the business, social and cultural activities they pursue. They comprise two large (by NZ standards) companies (NT and MT) and two small organizations (WTKI and TWOWT). The annual reports cited can be accessed at the following websites:

NT (http://ngaitahu.iwi.nz/investment/ngai-tahu-annual-reports/),

WTTKI (http://versite.co.nz/ 2014/17393/\#1/z),

TWOWT (http://www.waipareira.com/news/annual-report-2014), and

MT (http://www.maoritelevision.com/about/about-maori-television/official-

publications).

A summary outline of these organizations is provided in the following paragraphs.

Te Rūnanga o Ngāi Tahu [Ngāi Tahu] is a Māori tribal authority with approximately 55,000 registered members, mainly in the South Island of New Zealand (Statistics New Zealand, 2013). The total value of collective tribal assets reported in its 2014 Annual Report was \$NZ 1.219 billion, with total equity of \$NZ 1.075 billion (Ngāi Tahu Group Financial Accounts, 30 June 2014, pp. 7-8). Ngāi Tahu is incorporated in New Zealand by the Te Rūnanga o Ngāi Tahu Act 1996. Ngāi Tahu engages in extensive commercial, administrative, social and cultural operations.

Waikato-Tainui Te Kauhanganui Incorporated [WTTKI] is a registered charity serving approximately 66,000 tribal members in the Waikato district (near Hamilton, North Island). WTTKI oversees commercial, administrative, social and cultural functions as trustee for Waikato -Tainui tribal beneficiaries. The combined equity of the trust in 2014 was approximately \$NZ 784 million, with total assets of \$NZ 1.1 billion (WTTKI Annual Report 2014, p. 6.)

Te Whānau o Waipareira Trust [TWOWT] is a multi-tribal urban Māori community service organization, established in 1984, based in Waitakere City (North Island). TWOWT has 560,000 members and is a registered charitable trust. It had equity in 2014 of \$NZ 26.9 million and total assets of \$NZ 29.1 million (TWOWT Annual Report 2014, p. 39). TWOWT fosters economic, social and community development of urban Māori and non-Māori by conducting 
programs in poor Māori demographic areas.

Māori Television [MT] is a statutory corporation, founded in 2003 and funded by the New Zealand Government, as the national indigenous broadcaster. MT aims to restore Māori language, Māori culture and the importance of Māori social and political issues by providing bilingual Māori broadcasting. MT's statement of financial position at 30 June 2013 showed equity of \$NZ 19.2 million and total assets of \$NZ 23.9 million (MT, Pürongo-ā-tau Annual Report 2013, p. 21). MT is accountable through an annual Statement of Intent to the House of Representatives, output agreements and quarterly progress reports, an annual report, and regular audits by the Office of the Auditor General.

\section{Analytical framework}

Māori business organizations are accountable to members of their particular hap $\bar{u}$ [sub-tribe], iwi [tribe], the wider Māori society of ancestors and descendants, and the natural environment (Jacobs, 1997). To acquire legitimacy in their community, Māori business organizations reflect core Māori cultural values in their annual reports. They have a strong focus on a "quadruple bottom line" of social, cultural, environmental and business goals (Te Puni Kōkiri [TPK], 2009).

After reviewing the governance and management processes of thirty Māori businesses, the TPK (New Zealand's Ministry of Māori Development) identified eight major Māori cultural values as:

- wairua (spirituality)

- tikanga (customary beliefs and practices)

- manaakitanga (caring for others)

- whanaungatanga (kinship bonds)

- kaitiakitanga (stewardship)

- $\quad$ utu (harmony and balance in relationships between human beings and Nature)

- mana (respect)

- rangatiratanga (leadership) (TPK, 2006).

These values have been aggregated into the following three broadly encompassing value dimensions by Craig et al. (2018), from whom the following descriptions are summarised.

Spirituality and customary beliefs (wairua, tikanga). Māori believe that spirituality pervades all reality; that ancestors are still with them; and that the memory of ancestors should be honoured. Terrestrial matters cannot be separated from belief that gods are personifications of 
the natural world and that ancestors (wairua) are ever-present spiritually. Māori do not separate the material world from the spiritual world. The Māori concept of tikanga refers to overarching customary protocols, beliefs and practices that guide Māori life.

Restoration and intergenerationalism (Whakapapa, manaakitanga, whanaungatanga, kaitiakitanga, utu). Māori conceive themselves as living in a period of renaissance, in which they are addressing issues that affected their ancestors, and them, after the arrival of Europeans. This reflects the intergenerationalism that is a cornerstone of Māori life.

Whakapapa is a powerful belief system for Māori. There is a high regard for the need to maintain balance $(u t u)$ in all dealings honouring previous generations, and to provide for present and future generations. Also highly valued is manaakitanga, the idea of nurturing relationships, looking after people, and respecting how others live (Mead, 2003, p. 29). Whanaungatanga gives greater explicit emphasis to the role of contemporary Māori in countering the impact of colonization and urbanization on extended family connections.

Kaitiakitanga is an inherent obligation present generations have to past generations (ancestors) and future generations to safeguard and care for the environment (Selby et al., 2010, p. 1; Durie, 1998, pp. 23-24). Therefore, kaitiakitanga has implications for how Māori businesses operate and are assessed. Spiller et al. (2011b, p. 223) emphasize that in the conduct of Māori business activity, kaitiakitanga leads to humans being viewed as "stewards endowed with a mandate to use the agency of their mana [spiritual power, authority, and sovereignty] to create mauri ora [conscious well-being] for humans and ecosystems - and this commitment extends to organizations." Kaitiakitanga emphasizes that Māori should counter any loss of control over the environment. (See also Spiller et al. (2011a)).

Governance, leadership and respect (Mara, rangatiratanga). Māori society value the accumulation of mana as "a spiritual authority and power" derived from the gods (Marsden, 1977, pp. 118-119). The effective power of mana comes from reciprocal social relationships and kinship bonds with parents, whānau [family], hapu and iwi. Possession of taonga [anything highly prized such as traditional Māori land] enhances mana and gives a person or group a sense of self in the community (türangawaewae) (Firth, 1959; Craig et al,, 2013; Wild, 2013).

Rangatiratanga is respect for leaders. Mead (2003, pp. 37-38) associated rangatiratanga with sovereignty, chieftainship, self-determination and self-management. Grove (1985, pp. 1112) noted that rangatiratanga included essential abilities to lead a tribe in meetings, war, strategy, agriculture, and management of resources. 
In the following section, we provide narrative examples of how Māori organizations address these value dimensions. We then elaborate on how Māori organizations express their accountability in terms of each of value. A common feature of this accountability is a distinctive concern for governance issues, future orientation, and the external environment.

\section{Examples of Accountability in Terms of Core Māori Values}

\subsection{Overview}

The core values Ngāi Tahu [NT] describes include the gaining of respect from families in the tribe [whanaungatanga]; developing respect for each other and the tribe [manaakitanga]; protecting the people, the environment, knowledge, culture, language and all of NT's resources for future generations [kaitiakitanga]; taking appropriate action [tikanga]; and acting ethically and with integrity [rangatiratanga] (Annual Report, 2011, p. 3). There is a strong emphasis on NT's place within the tribe and its ethical conduct in serving the tribe.

Similarly, a WTTKI report, Whakatupuranga Waikato Tainui 2050, outlines the organization's core values of humility [whakaiti]; trust and faith [whakapono], love and respect [aroha]; peace and calm [rangimarie], caring [manaakitanga], unity [kotahitanga], and collaboration [mahitahi]. The report emphasizes ethical management, governance, working for the benefit of the tribe, and providing "a springboard for the preservation of Māori culture in the face of Pākehā colonization." Maintaining tribal identity, distinctiveness, and integrity is important, as is supporting caretakers of mattauranga [knowledge] and repositories of te reo [language] and tikanga. The preservation of land, rivers, lakes and other waterways is highlighted as important also, not only as assets, but also as living embodiments of tribal identity: "We are defined by our land, our river, our history ...We are our river, our river is us. ... The Waikato River represents the mana and mauri of Waikato-Tainui and is a living entity, a mauri that is an inseparable part of our whakapapa and identity" (Annual Report, 2014 , p.4). A high priority is placed on recovering lands and mana lost in colonization.

TWOWT reports reveal strong concern for whānau as a key component of any community. They explain the need to restore whänau as effective conduits of culture, role models, guardians and successful economic units. TWOWT describes its mission is to become an influential Māori organization [mana]; a leader of change in the delivery of services for Māori by Māori [rangatiratanga]; and a best practice provider of services to whänau. An important aim is that whānau "will be ... confidently participating in te ao Māori (the Māori world)", whilst being “cohesive, resilient and nurturing" (Annual Report 2014, p. 10). An over-arching objective for TWOWT is to be unified as one broad family. 
Māori Television [MT] states that two important values for it are respect and empathy (kia aroha) and the maintenance of core Māori values (kia Māori) (www.maoritelevision/com). MT's Annual Report (2009, p. 29) declares that its purpose is to "protect and promote te reo Māori [Māori language] and ... to provide a service to the public of New Zealand as opposed to that of making a financial return".

\subsection{Spirituality}

A notable feature of the reports of the four Māori entities is the high frequency of references to spirituality. This is something found rarely in Western-based financial reports. Each of the reports included a mihi [ritual greeting, acknowledgement, tribute]. A mihi links the past and the present, and often pays tribute to the universe (which includes the Sky Father, the Earth Mother, rivers, mountains), ancestors, ancient homelands, visitors, and people from the local area. The four Māori organizations each refer to the spiritual guidance they benefit from in all aspects of their undertakings. NT, for example, state: "Our goal is that our taha wairua [spiritual wellbeing] will flourish through the passion and energy we have to preserve and strengthen our culture" (NT Annual Report, 2013, p. 9). An example of this emphasis on spiritual underpinnings of activities occurs in the recounting of a legend to explain the spiritual origin of glacial hot pools (NT Annual Report, 2009, p. 17). Another example is MT's stated human resources policies. These refer to the promotion and maintenance of positive staff well-being, staff relationships and wairua [soul, spirit, quintessence].

\subsection{Intergenerationalism and Restoration}

The annual reports of all four Māori organizations emphasize the importance of well-being and the ongoing sustainability of culture, language, environment, resources and knowledge. Common terms used include "future generations", "protect", "grow", "nurture" and "enrich." Stewardship is a matter of concern to them, not just for commercial reasons, but for cultural reasons, including the preservation of resources (such as the Waikato Raupatu River) for future generations. The WTTKI Annual Report for 2009 cited an "overarching purpose ... to restore and protect ... the river for future generations" (p. 22). NT stressed its commitment to protect the people, environment, knowledge, culture, language and resources because of their importance for future generations.

Development of the NT tribe in intergenerational terms was acknowledged in outlining the annual capital distribution (dividend). This illustrated a strong commitment to balance the 
needs of current and future generations (Annual Report, 2013, p. 7). NT's concern for environmental capital was reflected in its reporting of the use of Global Positioning System (GPS) technology to pin-point specific stands of trees and areas of vegetation that should remain untouched to ensure the integrity of the natural landscape (NT Annual Report, 2009, p. 17).

In terms of restoration, a specific goal of MT is language revitalization - an activity which it claims "remains at the heart of everything we do" (Annual Report, 2012, p. 5). A key goal motivating service delivery by NT was the development of future leaders. NT also stated its intent to protect customary tribal rights; to ensure the well-being and security of those rights and other assets; and to preserve Treaty of Waitangi settlement rights and other elements crucial to the tribe's culture and identity. NT aspired to achieve long-term sustainable returns through the development of a sustainability framework "for us and our children after us" (Annual Report, 2009, p. 10). NT expressed a commitment to ensure that the values and behaviours required to protect stakeholder interests were embedded in everything they did. This was illustrated by their committed planning for NT fisheries. They stated that "we will continue to address this [succession planning] as a strategic priority. Any initiatives must be mutually beneficial for Ngāi Tahu Seafood, Ngāi Tahu fishers and the wider iwi interests" (Annual Report, 2009, p. 15).

In terms of intergenerationalism, the reports of NT and WTTKI aspirate to provide prosperity for future generations. Both refer to specific initiatives to increase financial wealth and provide future leaders, such as by investing in education grants, creating employment opportunities, protecting culture, and ensuring resource sustainability. NT reported that they funded out-of-school tuition because children represent the collective future of the $i w i$. NT also reported funding initiatives to protect and develop students' cultural well-being. The importance of the ongoing relationship of the tribe to the natural environment, especially insofar as this comprises its tūrangawaewae [place of belonging through kinship and whakapapa], is emphasized in statements such as:

Our dream is that our ancestral landscape is protected and our people have living relationships with their whakapapa and traditions through the environment. The goal is that Ngāi Tahu is a principled kaitiaki (guardian) of our takiwā (territory, area) (NT, 2013, p. 3).

The long-term view of inter-generational wealth, outlined by WTTKI in Whakatupuranga 2050 , is a blueprint for the cultural, social and economic advancement of their people. This is described in the WTTKI annual report as "a fifty-year development approach to building the 
capacity of our $i w i, h a p \bar{u}$ and marae [meeting place]. Whakatupuranga 2050 will be our legacy for those who come after us" $(2009$, p. 7).

Various annual reports of MT reflect its positioning as a steward for past, present and future Māori. MT highlights its responsibility for the delivery, quality and consistency of the Māori language; and for developing programming initiatives to enrich New Zealand society, culture and heritage. MT regards the preservation and valuing of Māori language and culture to be a non-economic aspect of intergenerational wealth. By revitalising and normalising the Māori language, MT believes it can help to build a collective sense of nationhood for all New Zealanders.

\subsection{Governance, Leadership and Respect}

Governance mechanisms of Māori organizations emphasize transparency and the importance of consultation and communication (see, for example, Wild 2013, p.13). Consultation in Māori organizations helps ensure that assets are protected for present and future generations, and that the likelihood of a minority benefiting to the detriment of a majority is reduced. The emphasis on consultation facilitates good stewardship of assets. This is apparent when Māori organizations are involved in complex commercial transactions involving the sale of assets (for example, the sale of fish quotas by NT).

The CEO of NT in 2009, Anake Goodall, linked the practice of face-to-face shareholder consultation to tribal tradition, stating: "While the importance of communicating kanohi ki te kanohi [face to face, in the flesh] will never diminish in our world, we are also continuing our tradition by adopting new technologies to reduce costs and to extend our communications reach" (NT Annual Report, 2009, p. 4).

All four Māori organizations mentioned how they address issues by acquiring guidance from elders, or by obtaining a unanimous mandate from tribal members on matters concerning the tribe's assets. Such a co-operative approach ensures consensus and aligns the organization with other values, such as respect and stewardship. WTTKI annual reports emphasize how the title of lands in their tribal estate signifies that those lands cannot be sold, alienated, mortgaged or gifted without a mandate from voting beneficiaries or their representatives, and unanimous consent of the custodial trustees.

In terms of leadership and respect, the annual reports of the four Māori organizations reflect a deep sense of respect and gratitude for the work of ancestors and an obligation to carry on their work and traditions. By maintaining grants to kaumātua [elders], NT honours those who have contributed to the NT vision over time. Further, because respect is important, NT strives to maintain a high degree of personal integrity and ethical behaviour in all of its actions and 
decisions.

TWOWT claims that its "internal process for whänau to access kai [food] ... maintains the mana [authority] of our Whānau" (Annual Report, 2009, p. 19). TWOWT acknowledges those who have helped them to achieve goals, including those now deceased. The Chair and CEO states in his report: "Our work is a journey ... started by some outstanding elders who have passed on and who contributed their everything..." (Annual Report, 2009, p. 3).

The MT annual report (2009, p. 8) acknowledges that the company's strong governance processes are enhanced by the work of a council of elders [Kaunihera Kaumātua]: "Maori Television is indebted to the guidance and wisdom of its council and elders, Kaunihera Kaumātua, which provides advice to the organization on matters of tikanga, kaupapa and kawa" (Annual Report, 2009, p. 4).

In many Māori organizations, ownership of tangible and intangible items carries an obligation to respect kinship bonds. Great importance is placed on respecting, fostering and maintaining relationships; emphasising the importance of family; and nurturing. These activities are similar to the concept of "social and relationship capital," outlined in the proposals of the International Integrated Reporting Council [IIRC] (2013, p.12). Māori recognize the value to an organization of developing and maintaining such social and relationship capital over the long term. NT emphasize the need to nurture and respect relationships within their organization, their $i w i$ and their community. NT Seafood Products stresses its respect for individual NT fishers and the wider interests of the $i w i$. Thus, a fish leasing business in which quotas are sold to non-Māori operates with the proviso that the buyers respect the right of NT fishers to on-going access to fishing areas and viable catch plans (NT Annual Report, 2009, p.15).

The TWOWT annual report stresses the need to uphold mana by always acknowledging Māori ancestry; by ensuring the whānau are the centre of their world; and by always striving to better themselves for the sake of their whānau. TWOWT operates a residential facility for children referred from a government agency. Thereby, they are well placed to demonstrate to young people how a family can resolve issues together. Their flagship model for future service delivery is family-centred. The key assumptions underpinning TWOWT's operational model are that families are at the centre of the TWOWT world; that all generations should be included; and that the long-term goal is to make families self-sufficient (Annual Report, 2009, p. 27). The TWOWT report includes letters of gratitude from Māori, non-Māori and international immigrants, reflecting the inclusive nature of the services it provides (Annual Report, 2009, p. 20). 


\section{Conclusions}

Developing an understanding of indigenous world-views (such as collective ownership, intergenerational wealth, and the prioritization of cultural considerations over economic factors) can be beneficial in many ways. First, it can raise awareness of how indigenous organizations operate their economic ventures to balance financial viability with social and cultural aspirations. Second, it can prompt further thought on how to conceptualize spirituality and stewardship. Third, it can lead to more emphasis being given to the importance of adopting a long-term view, as sought by the IIRC (2013). If a broader shift occurs in corporate reporting towards a longer term perspective, there is enhanced prospect of improved sustainability outcomes (Tweedie and MartinovBennie, 2015). We should acknowledge too that many of the concepts inherent in integrated reporting reflect values already embodied in the underlying aims, principles, culture and governance of indigenous (here Māori) organizations.

The topic of whether, and if so how, indigenous values should be incorporated in accounting and accountability reports is under-explored. There is considerable merit in prioritising research on indigenous values, and in exploring how to apply those values in accounting and accountability frameworks, especially in societies which claim to be multi-cultural. Moreover, raising awareness of what is important to indigenous communities, and how accountability and governance can differ for them, can benefit all stakeholders.

In a globalized context, large-scale multinational business enterprises confront a diverse range of increasingly vulnerable environmental, social and political settings, and demanding complexity in notions of 'value'. The potential for accounting ideologies and practices to incorporate new modes of understanding, and to develop a more effective form of integrated reporting, should be embraced. Explicit commitment to diversity will help develop a more enabling accounting. Thus, greater attention should be given to drawing upon the future-oriented, inclusive, and sustainability-supporting values of indigenous communities to inform future accountability reforms. Future research should explore how to redirect these values to show how other businesses could implement (and measure) them.

\section{References}

Brown, J., \& Dillard, J. (2013), "Critical accounting and communicative action: On the limits of consensual deliberation”, Critical Perspectives on Accounting, Vol. 24 No. 3, pp. 176190.

Craig, R., Taonui, R., \& Wild, S. (2013), “The concept of taonga in Māori culture: insights for 
accounting”, Accounting, Auditing \& Accountability Journal, Vol 25 No 6, pp. 1025 - 1047.

Craig, R., Taonui, R., Wild, R., \& Rodrigues, L.L. (2018), "Indigenous cultural values and accountability reporting", University of Canterbury Working Paper (Department of Accounting \& Information Systems), currently under review.

Durie, M. (2006). Measuring Māori Wellbeing. New Zealand Treasury, Guest Lecture Series 2006. Accessed 1 August 2010 at: http://www.treasury.govt.nz/publications/mediaspeeches/guestlectures/pdfs/tgls-durie.pdf

Durie, M., Fitzgerald, E., Kingi, Te K., McKinley, S., \& Stevenson, B. (2002). Māori Specific Outcomes and Indicators: A Report prepared for Te Puni Kōkiri, the Ministry of Mãori Development. School of Māori Studies, Massey University, Palmerston North.

Durie, M. (1998), Te Mana, Te Kāwangatanga - The Politics of Māori Self-determination, Oxford University Press, Auckland.

Firth, R. (1959), Economics of the New Zealand Māori, New Zealand Government Printer, Wellington.

Grove, R.N. (1985), Te Whatanui: Traditional Māori Leader, MA thesis, Victoria University of Wellington.

Harding, S. (2008), Sciences from Below: Feminisms, Postcolonialities, and Modernities, Duke University Press, Raleigh, NC.

Henry, E., \& Pene, H. (2001), “Kaupapa Māori: locating indigenous ontology, epistemology and methodology in the academy", Organisation, Vol. 8 No. 2, pp. 234- 242.

International Integrated Reporting Council [IIRC] (April, 2013), International Integrated Reporting Framework, accessible at http://www.theiirc.org/wp-content/uploads/2013/12/13-12-08-THE-INTERNATIONALIR-FRAMEWORK-2-1.pdf (accessed 27 March, 2015).

Jacobs, K. ( 2000), "Evaluating accountability: finding a place for the Treaty of Waitangi in the New Zealand public sector", Accounting, Auditing \& Accountability Journal, Vol.13 No.3, pp. $360-380$.

Jacobs, M. (1997), “The environment as stakeholder”, Business Strategy Review, Vol. 6 No. 2, pp. 25-28.

Love, T.R. (2017), "Mãori values, care and compassion in organisations: A research strategy." Paper presented at the $33^{\text {rd }}$ European Group for Organizational Studies Colloquium, Copenhagen Business School, Denmark.

Marsden, M. (1977), “God, man and universe: a Māori view.” In King, M. (Ed.), Te Aohurihuri: Aspects of Māoritanga, Reed, Auckland. 
McNicholas, P. (2009), “Māori development: 'accounting', 'accountability': and participation in the accountancy profession", Pacific Accounting Review, Vol. 21 No. 3, pp. 319-324.

Mead, S.M. (2003), Tikanga Mãori: Living by Mãori Values, Huia Publishers, Wellington.

Selby, R., Moore, P., \& Mullholland, M. (Eds) (2010), Māori and the Environment: Kaitiaki, Huia Books, Wellington.

Spiller, C., Erakovic, L., Henare, M., \& Pio, E. (2011a), "Relational well-being and wealth: Māori businesses and an ethic of care”, Journal of Business Ethics, Vol 98 No. 1, pp 153169

Spiller, C., Pio, E., Erakovic, L., \& Henare, M. (2011b), "Wise up: Creating organizational wisdom through an ethic of Kaitiakitanga", Journal of Business Ethics, Vol. 104 No. 2, pp. 223-235.

Statistics New Zealand (2013), Steady growth in Māori population continues (accessed 8 November 2014). http://www.stats.govt.nz/Census/2013-census/profile-and-summaryreports/qstats-about-maori-english-mr.aspx

Te Puni Kōkiri [TPK] (2006), Investigating Key Māori Business Characteristics For Future Measures: $\quad$ Thinking $\quad$ Paper, http://www.tpk.govt.nz/en/in-print/ourpublications/publications/for-Māori-future-makers/download/tpkkeybusnessmeasures.pdf

Te Puni Kōkiri [TPK] (2009), The Implications of a Recession for the Māori Economy, http://www.tpk.govt.nz/

Tweedie, D., \& Martinov-Bennie, N. (2015), “Entitlements and time: integrated reporting's double-edged agenda", Social and Environmental Accountability Journal, Vol. 35, pp. 4961.

Wild, S. (2013), “Accounting for heritage, cultural and community assets: Alternative metrics from a New Zealand Māori educational institution”, Australasian Accounting Business and Finance Journal, Vol. 7, No. 1, pp. 3-22.

Winiata, W. (2006), "Measuring wellbeing of communities: Hapū, iwi, regions and nations", accessed 15 July 2010 at: http://www.wananga.com/docs/pdfs/Papers\%20by\%20Whatarangi\%20Winiata.pdf

\section{Appendix. Glossary of Māori words}

$\begin{array}{ll}\text { Aotearoa } & \text { New Zealand } \\ \text { aroha } & \text { love and respect } \\ \text { hapu } & \text { kinship group or sub-tribe } \\ \text { iwi } & \text { tribe }\end{array}$




$\begin{array}{ll}\text { kaupapa } & \text { rightful cause } \\ \text { kaimoana } & \text { seafood } \\ \text { kaitiaki } & \text { guardian } \\ \text { kaitiakitanga } & \text { guardianship, stewardship } \\ \text { kaumātua } & \text { elders } \\ \text { kotahitanga } & \text { unity } \\ \text { mahitahi } & \text { collaboration } \\ \text { mana } & \text { authority - power derived from the gods } \\ \text { manaakitanga } & \text { looking after people, caring } \\ \text { marae } & \text { customary centres } \\ \text { mātauranga } & \text { education and knowledge } \\ \text { mauri } & \text { life-force } \\ \text { mauri ora } & \text { conscious well-being } \\ \text { Pākehā } & \text { Non-Māori of European descent } \\ \text { rangatira } & \text { chiefs } \\ \text { rangatiratanga } & \text { leadership } \\ \text { rangimarie } & \text { peace and calm } \\ \text { rūnanga } & \text { councils } \\ \text { taonga } & \text { highly prized property } \\ \text { te reo } & \text { Māori language } \\ \text { tikanga } & \text { customary principles, protocols, practices, appropriate action } \\ \text { tüpuna } & \text { ancestors, past generations } \\ \text { tūrangawaewae } & \text { sense of homeland } \\ \text { utu } & \text { harmony and balance between human beings and Nature } \\ \text { wairua } & \text { spirituality } \\ \text { whakaiti } & \text { humility } \\ \text { whakapapa } & \text { genealogy from creation linking all living and non-living } \\ \text { whakapono } & \text { trust and faith } \\ \text { whānau } & \text { family or families } \\ \text { whanaungatanga } & \text { family } \\ \text { whenua } & \text { land and/or placenta } \\ & \end{array}$

